\title{
Accountability in agricultural governance and food security in Nigeria
}

\author{
Responsabilidade na governança agrícola e segurança \\ alimentar na Nigéria
}

\author{
Romanus Osabohien $^{1,2^{*}}$ (1), Daniel Ufua ${ }^{2,3}$, Chinonye Love Moses ${ }^{4,3}$, Evans Osabuohien ${ }^{1,2,4}$ (I) \\ ${ }^{1}$ Covenant University, Department of Economics and Development Studies, Ota - Nigeria \\ ${ }^{2}$ Covenant University, Centre for Economic Policy and Development Research (CEPDeR), Ota - Nigeria \\ ${ }^{3}$ Covenant University, Department of Business Management, Ota - Nigeria \\ ${ }^{4}$ Covenant University, Regional Centre of Expertise (RCE Ogun), Ota - Nigeria
}

*Corresponding Author: Romanus Osabohien, Covenant University, Department of Economics and Development

Studies, Km 10, Idiroko Road, Ota - Nigeria, e-mail: romanus.osabohien@covenantuniversity.edu.ng

Cite as: Osabohien, R., Ufua, D., Moses, C. L., \& Osabuohien, E. (2020). Accountability in agricultural governance and food security in Nigeria. Brazilian Journal of Food Technology, 23, e2019089. https://doi.org/10.1590/1981-6723.08919

\begin{abstract}
This study explores the relationship between agricultural governance and food security in Nigeria and employs two main approaches: descriptive and econometric. The econometric approach engages Autoregressive Distribution Lag (ARDL) in examining the long-run relationship between the indicators of food security and agricultural governance for the period 1985 to 2016. The results show that in the long-run, agricultural performance contribute to food security in Nigeria. The findings from the descriptive analysis unveil that Nigeria has the highest number of undernourished people, which increased by 22\% between 2000 and 2001. Between 2000 and 2015, the population grew by $30.60 \%$ with the rate of violence increasing by $55 \%$. The study recommends, among others, that accountability in addressing the challenges in the implementation of food security programs and ensuring timely distribution of food resources is germane.
\end{abstract}

Keywords: Accountability; Agriculture; Food security; Governance; Food waste; Institutions.

\section{Resumo}

Este estudo explora a relação entre governança agrícola e segurança alimentar na Nigéria. Emprega duas abordagens principais para alcançar seu objetivo: descritiva e econométrica. A abordagem econométrica envolve o atraso de distribuição autorregressiva (ARDL) no exame da relação de longo prazo entre os indicadores de segurança alimentar e governança agrícola, para o período de 1985 a 2016. Os resultados mostram que, a longo prazo, o desempenho agrícola contribui para a segurança alimentar na Nigéria. Os resultados da análise descritiva revelam que a Nigéria tem o maior número de pessoas subnutridas, que aumentou $22 \%$ entre 2000 e 2001, enquanto, entre 2000 e 2015 , a população cresceu $30,60 \%$, com a taxa de violência aumentando $55 \%$. O estudo conclui recomendando, entre outros, que a responsabilidade de enfrentar os desafios na implementação de programas de segurança alimentar e garantir a distribuição oportuna dos recursos alimentares é pertinente.

Palavras-chave: Responsabilidade; Agricultura; Segurança alimentar; Governança; Desperdício de alimentos; Instituições. 


\section{Introduction}

The challenge of effective food security has remained a critical issue for consideration by various government admirations in Nigeria (Osabohien et al., 2020; Ejikeme et al., 2017); because, food security stands as an important factor for human survival (Babatunde et al., 2007; Titus \& Adetokunbo, 2007; Dias et al., 2017).Extant studies have presented the subject of food security from several perspectives: government's involvement, climate change and the need for availability of food and related resources for human consumption (Osabohien et al., 2019a; Ike et al., 2017).

Despite the effort of successive government administrations in Nigeria, non-governmental organizations (NGOs), and the international agencies, the challenge of achieving food security has remained a herculean task (Osabohien et al., 2018b). However, while the government has made frantic efforts through various budgetary allocations, supports from international agencies, and so on (Matthew et al., 2019a, 2019b). Androsova et al. (2016) the instrumentality of accountability, equitable distribution and preservation of food resources, which could lend relevant support in ensuring food security tend to have been inadvertently neglected in the literature. These factors motivate our study, which draws the attention of academia and practitioners to the need for accountability in the area of food distribution, in line with appropriate government policies.

While there are several studies on food waste (e.g. Ayotamuno \& Gobo, 2004; Thi et al., 2015), the study addresses the subject of waste from the perspective of the involved and affected stakeholders. This study recognizes the contextual meaning of waste rather than the universal meaning (Womack \& Jones, 2003). The study, therefore, underlines the subject of waste as an ongoing debate, which only the affected stakeholders should be involved in defining

Evidence from the Living Standards Measurement Study-Integrated Survey on Agriculture (Osabohien et al., 2020) showed that in 2015, about 26.4\% of households reported food reduction in Nigeria. This reduction in food depicts 2.3\%-point increase from 2015. This number is significantly higher in some of the geo-political zones in Nigeria. In the South-South and North-East of Nigeria, the share of households with a reduced number of meals increased by $14.1 \%$ and $6.3 \%$ points, respectively (Osabohien et al., 2020). Moreover, in the urban area, households $(29.8 \%)$ reported the incidence of food reduction than rural households, which was $24.1 \%$. Overall, about $19.6 \%$ of households reported food inadequacy in in 2016 . The percentage is considerably higher in the South East with the value of $34.3 \%$.

However, from LSMS-ISA (Osabohien et al., 2020) the share of households' food inadequacy is considerably high across the Nigerian regions. In the South-West and North-East, $22 \%$ and $20.3 \%$ of Nigeria's households reported to be food insufficient, respectively. More urban households (23.5\%) reported food inadequacy than rural households $(16.9 \%)$. The highest proportion of households reported shortages in January $(50.3 \%)$ and February (32.8\%). This pattern is the same for the three southern zones. However, there are important differences in the northern zones. The month where food shortages were most common is July in North Central (49.4\%), August for North East (58.2\%) and February for North West (30.7\%). Increase of food prices due to ineffective price control through governance is the major cause of greater concern among rural (15.3\%) than urban households $(8.3 \%)$.

The above is essential as the challenge of distribution along the relevant value chain has resulted in the scarcity of certain food resources. Hence, the poor and lower class of the society are usually excluded through hiked prices occasioned by increased cost along the value chain. This points out the need for strong value chain and distribution of food resources in terms of food management in the interest of citizenry (Ufua et al., 2018). Accountability in the context of this study, promotes the use of records and data for planning food security issues, with due attention given to all stakeholders who are either involved or affected in the planning and implementation of food security programs (Fritschel et al., 2015). This could be achieved through the practice of meaningful engagement with the stakeholders at each stage of the implementation of food security programs (Ufua et al., 2018). This would result in mutual understanding between the stakeholders and the 
interveners that may undertake the task of designing the right food distribution strategy and facilitate a conflict-free platform to execute the task of accountable food distribution (Womack \& Jones, 2003; Ufua et al. 2015; Osabohien et al., 2019b).

The study is structured as follows: the next session presents the literature review, followed by the adopted methodology, next is discussion and the last session is conclusion, which includes managerial implications, and suggestions for further research.

\section{Key Issues from the Literature}

In rethinking the strategies for sustainable development in ensuring food security in Nigeria, the potentials of agriculture can be enhanced through institutional frameworks, governance and accountability. From the empirical study of Osabohien et al. (2018b) employing the Auto-regressive Distributed Lag (ARDL) technique in examining the role of institutional framework on food security, pointed out that institutional framework in Nigeria exerts a negative effect on food security, due to weak institutional quality in Nigeria. According to Osabohien et al. (2018a) the Nigerian agricultural sector remains an important sector of the economy, owning to the fact that the sector employs approximately $75 \%$ of the total work force, especially in the rural communities where most of the farmers earn their livelihood.

A study by Munene et al. (2018) employed the adaptive governance approach and noted the need to redirect strategies to achieve sustainable development. This would be more effective through the implementation of the framework requiring non-traditional management and governance approaches for substantial reduction of food waste. It was noted that Adaptive governance (AG) has been known to be the medium to drastically change the link between development and disaster risk, with potentially far-reaching implications for policy and practice to ensure food security. Osabuohien et al. (2018c) used qualitative method with focus group discussion to examine how local institutions contribute to food (rice) production in Ogun State, Nigeria where they pointed out that local institutions play a key role in food production. In the study by Herbel et al. (2012), it was shown that achieving food security and the enhancement of dietary level is at the heart of the Sustainable Development Goals (SDGs). In line with that, Sidibé et al. (2018) noted that achieving food security can be done through the enforcement of rules and laws designed at the national level which remains one of the central institutional mechanisms for efficient multi-scale governance in most countries.

According to Osabohien et al. (2019c) policymakers are increasingly enlightened on the food security perspective, which has over the years reflected poorly in institutional terms. This study fills this gap by addressing the question as to what forms of accountability and governance is more appropriate to govern food systems in a more holistic way to achieve sustainable development goals (SDGs) by year 2030. In Africa, food security in relatively is high on the policy agenda of governmental authorities all over the globe (Candel, 2014). 'Food security governance' relates to the 'formal and informal' rules and processes through which interests are expressed, and decisions which are germane to food security in a country are prepared, implemented and enforced on behalf of members of society.

Studies by Rodrik (2010), Osabuohien et al. (2018c) to achieve food security reveal the need for equal opportunity in resource allocation and the delivery of services; coherent and coordinated policies, institutions, and actions. This means that the challenge for policymakers interested in addressing the key policy issues are to redesign strategies that allow countries to have a stable and affordable food supply that is equitably distributed as household food insecurity continues to be widespread with strong inequities across and within countries governance and strategies. Given the pathetic economic situation in some critical parts of the country, for example; the north east (Scribner, 2017; Ajayi \& Adenegan, 2018), where starvation has been prevalent due to insurgency, the use of the right approach to addressing the national challenge of food insecurity, based on a platform of accountability, have remained a maximum requirement for achieving the right results of this subject area. Thus, from the fallouts in the literature, this study addresses the gaps in knowledge and takes up the debate to a new level with respect to the issues of food security and accountability in Nigeria. 


\section{Methodology}

\subsection{Empirical model}

The food system concept is poorly reflected in institutional terms at local, national, and international levels (Osabuohien et al., 2018c). Approaching food insecurity issues from systems perspective reveal and in turn enhance important governance challenges and opportunities, because, it requires more holistic approach to fully address. By its nature, food governance institutions are fragmented and cut across the usual boundaries between sectors, administrative jurisdictions, public and private domains, temporal and spatial scales and diverse normative frameworks.

The study applied econometric and descriptive approaches to achieve its objective. The study engaged time series data from 1985 to 2016 sourced from the Central Bank of Nigeria (CBN) statistical bulletin, World Governance Indicators (WGI), World Development Indicators (WDI) and Food and agricultural Organization (FAO). The descriptive approach engaged tables in examining the state of food security in Nigeria in relation to Economic Community of West African States (ECOWAS) sub-region threshold, while the econometric method employed the Autoregressive Distribution Lag (ARDL) to examine the long-run relation between governance and food security. The study adopted the Malthusian theory of population growth model and states the implicit function of the model as shown in Equation 1:

$Y_{t}=f\left(A_{t}---, X_{t^{-}}, Z_{t}\right)$

Where $A_{t}=A G R I C P R O_{t}, A G C S F_{t} ; X_{t}=P O P_{t} ; S_{t}=C C_{t}, V A_{t}, R L A W_{t}, P S A V_{t}$

Where Y represents food security proxied by number of people undernourished, A represents agricultural production and agricultural credit guarantee scheme fund; $\mathrm{X}$ represents population growth; $\mathrm{Z}$ represents the four governance components used in this study which are: control of corruption, voice and accountability, rule of law, and political stability and absence of violence. Insight of the ARDL model is drawn from the study of Osabohien et al. (2018a). The reason for the use of ARDL approach to cointegration is built on the premise that time series variables trend in difference order of stationarity, hence the traditional approach to cointegration becomes inefficient.

$$
\begin{aligned}
& \Delta n p u_{t}=\beta_{0}+\sum_{t=1}^{n} \beta_{1} \Delta \text { agricpro }_{t-1}+\sum_{t=0}^{n} \beta_{2} \Delta \text { acgsf }_{t-1}+\sum_{t=0}^{n} \beta_{3} \Delta \text { pop }_{t-1}+\sum_{t=0}^{n} \beta_{4} \Delta c c_{t-1} \\
& +\sum_{t=0}^{n} \beta_{5} \Delta v a_{t-1}+\sum_{t=0}^{n} \beta_{6} \Delta \text { rlaw }_{t-1}+\sum_{t=0}^{n} \beta_{7} \Delta p s a v_{t-1}+\gamma E C M_{t-1}+e_{t}-
\end{aligned}
$$

Where: $\Delta$ is the change in operator and the $E C M_{t-1}$ denotes error correction term. $\gamma$ represents the speed of adjustment from the short-run to the long-run equilibrium Given the above, the ARDL model is represented in Equation 4

$$
\begin{aligned}
& \Delta n p u_{t}=\beta_{0}+\sum_{t=1}^{n} \beta_{1} \Delta_{\text {agricpro }_{t-1}}+\sum_{t=0}^{n} \beta_{2} \Delta \text { acgs }_{t-1}+\sum_{t=0}^{n} \beta_{3} \Delta \text { pop }_{t-1}++\sum_{t=0}^{n} \beta_{4} \Delta c c_{t-1}+ \\
& +\sum_{t=0}^{n} \beta_{5} \Delta v a_{t-1}+\sum_{t=0}^{n} \beta_{6} \Delta \text { rlaw }_{t-1}+\sum_{t=0}^{n} \beta_{7} \Delta p s a v_{t-1} e_{t-1} \\
& H_{0}: \beta_{0}=\beta_{1}=\beta_{2}=\beta_{3}=\beta_{4}=\beta_{5}=\beta_{6}=\beta_{7} \text { (No long run relationship exist) } \\
& H_{1}: \beta_{0} \neq \beta_{I} \neq \beta_{2} \neq \beta_{3} \neq \beta_{4} \neq \beta_{5} \neq \beta_{6} \neq \beta_{67} \text { (Long run relationship exist) }
\end{aligned}
$$

The dependent variable, food security is proxied by the number of people who are undernourished (npu). Agriculture is proxied by agricultural production and Agricultural Credit Guarantee Scheme Fund, population as the number of people. The study builds on Malthusian theory of population. This is because according to Malthus theory, population grows exponentially while food production grows arithmetically doubling with each cycle; in this wise, while food production is likely to increase in a series of twenty-five-year intervals in the arithmetic 
progression; population is capable of increasing in the geometric progression. This situation of arithmetic food growth with simultaneous geometric human population growth predicted a future when people would have no resources to survive with. This means many people tends to chase few available food in turn leads to food insecurity. The data, sources and measurement of the variables for the study are presented in Table 1:

Table 1. Data source and measurement.

\begin{tabular}{|c|c|c|c|}
\hline Data & Identifier & Data Source & Measurement \\
\hline Food security & $\mathrm{Npu}$ & FAO (2017) & number of people undernourished ( $\%$ of total population) \\
\hline \multirow{2}{*}{ Agriculture } & agricprod & \multirow[t]{2}{*}{ CBN (2016) } & Total volume of agriculture production \\
\hline & Acgsf & & Credit to agricultural sector in Nigerian naira $\left(\mathrm{N}^{\prime} 000\right)$ \\
\hline \multirow{4}{*}{ Governance } & $\mathrm{Cc}$ & \multirow{4}{*}{$\begin{array}{l}\text { Wold Bank- WGI, } \\
\text { (2019) }\end{array}$} & \multirow{4}{*}{ Institutions } \\
\hline & Rlaw & & \\
\hline & Psav & & \\
\hline & $\mathrm{Va}$ & & \\
\hline Population & population & $\begin{array}{l}\text { World Bank- WDI } \\
\qquad(2019)\end{array}$ & Total number of people \\
\hline
\end{tabular}

Note: FAO means Food and Agricultural Organization of the United Nations; CBN means Central Bank of Nigeria; WGI means World governance indicators; WDI means World Development Indicators. Source: World Bank (2019a, 2019b).

\section{Results and discussion}

This section presents the results obtained from the two methods of analysis: the descriptive and econometric methods engaged in the study presented in sub-sections (4.1) and (4.2)

\subsection{Descriptive results}

Despite of the overall progress in reducing food insecurity across the world, West Africa remains the region with the highest number of people who are under or malnourished (Food and Agricultural Organization of the United Nations, 2017). Some countries have shown progress in terms of food security in recent years, this progress occurred in most countries in Europe, Eastern and South Eastern Asia, as well as in Latin America, while Nigeria showed no progress as the country lags among West African countries. Food security can be referred to the state where all people always have physical, social, and economic access to adequate, safe and nourishing food which meets their dietary needs and food preferences for an active and healthy life (Food and Agricultural Organization of the United Nations, 2017).

United Nations Sustainable Development Goals (SDGs) aims to transform the world economies by year 2030 with 17 specific goals of which the second goal that is, achieving food security and improving nutrition and promoting sustainable agriculture is specifically focused on food and nutrition. It aims at achieving sustainable food security, end of all forms of malnutrition, double the agricultural production and income of small-scale food producers, and ensure sustainable food security.

In this study, we have considered some necessary indicators of food security which are: Number of people who are undernourished, Political stability and Absence of Violence/Terrorism; per capita food supply variability, Per capita food production variability and Total population. As presented in Figure 1 


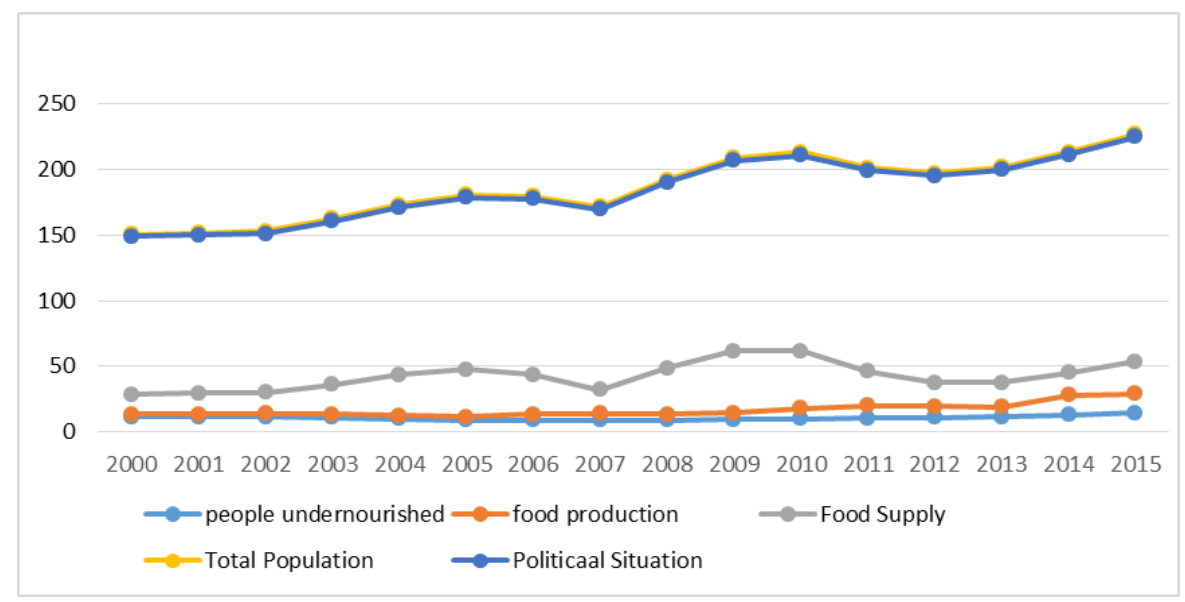

Figure 1. State of food security indicators. Source: Authors'.

Addressing the food security issue in Nigeria demands prompt accountability which could help demarcate the current situation in its entirety, highlighting the key areas affected, and encourage advancement of relevant methods that can resolve the issue. This would create a platform of food supply resilience aimed at keeping the developed approach on a rapid response to emerging food security challenges. Accountability, among other factors points to the fact that food security would pose the challenge of low per capita productivity, especially in food production, which is relevant to food security.

Figure 1 shows the food production level measured as food production variability in West African countries. Nigeria ranked third among the countries that with the lowest figure (ranging between 2.4 to 14.5). It shows the inadequacy of the current food security systems, insufficient resource availability and accountability on the use of resources during the period under review. These challenges therefore call for improvement on the current investment profiles on food production and security. It is widely believed in literature that increase in production generates more food capable of reducing food shortage and the exclusion of the poor as a result of hunger as experienced in France and England (Fogel, 2004). The improving supply of food in both countries showed efficient production of food systems. In terms of food production, Nigeria as the most populated country in Africa with over 180 million people lags behind other West African countries as its food production observed to be lower. In this regard, more attention is needed to boost food production, food preservation and distribution, which could form a notable base for projecting the entire economy to better performance in the future. Collaboration with supportive agencies could be helpful.

In line with the above, it was observed that in Mali, the food production (especially food crops) has conventionally formed the bedrock for the pursuit of food security agenda (Sidibé et al., 2018). This idea has been a long position of giving main concern of successive governments since Mali's gained independence, in 1960. Structural responses to food insecurity in Mali have mainly consisted of strategic reforms to enable the nation to enhance agricultural production for the attainment of food security (Bélières et al., 2008).

Per capital food supply variability is another main indicator for measuring food security. Food supply variability results from a combination of instability and responses in production, trade, consumption and storage, in addition to changes in government policies such as trade restrictions, taxes and subsidies, stockholding and public distribution (Osabohien et al., 2018b). In Nigeria, unevenly distribution of food probably reflects in price instability, which effects vulnerable households' ability to make long-term adjustments to their resource constraints (Lele et al., 2016). It is necessary to understand the nature of fluctuations in a food system which can aid scholars and policy makers on the strategies to be employed in enhancing the food systems in Nigeria.

It has been predicted that food demand will increase in the coming years in all countries, especially Nigeria with high population and to off-set this food demand, strategies for efficient and effective supply of food to 
all households in Nigeria needs to be put in place to avert food shortage, and this can be done is through innovation (like warehouse and other storage facilities, Osabohien et al., 2019c). Populations spread of countries in West African sub-region during the period under review. Nigeria, which is the focus of this study has high population growth rate. This has not been reflected on food production and security practice in Nigeria. Instead, the growth in national population has resulted in a further complexity in terms of availability of food that meets the demands of the population density, especially in urban areas where food production is minimal and the demand is high (Ojo, 2004; Echebiri \& Edaba, 2008; Jhingan, 2003)

Because food security involves different aspects which are made up of: availability, access to food and food utilization, its strategies has to be essentially engaged by government, non-government organisations. Food security governance can be said to have two main interactions: the formal and informal interactions' which cut across balance among public and private individuals with the goal of achieving food security (Candel, 2014). experience of agriculture and food governance in Brazil and South Africa have confirmed that food security situation can be considerably enhanced by adopting three essential procedures such as: creating a new social policy programmes, formulation of an agency exclusively to manage the effort of other ministries in quest for food security objectives and together with stakeholders in the decision-making procedure

Effective food security governance requires a broad, systems think, problem-solving strategy which tackle the difficulty of food security, cut across national, regional, and local levels, and is adjustable across time. When governments fail to tackle the crisis situations in nation and structural factors, they invariably fail to address food security and its affect (Shamah-Levy et al., 2017; Candel, 2014). Ironically, results obtained showed that Nigeria food security governance has taken on post-political uniqueness which hampers rather than enhancing growth of ending food shortage and achieving the right to food for all. Quantitative details about the absence of terrorism in West African sub-region. The data describes the level of security of life and property among West African countries.

Compared to other West African countries, Nigeria ranks as a high-risk country on this record as its political stability and absence of violence continues to be negative and higher than other regional countries [-5.2 in 2001; - 2.7 in 2015] (Food and Agricultural Organization of the United Nations, 2017). This could be traceable to the inherent crises' herdsmen in both the northern and southern parts of the country as the violence between the Fulani herdsmen and farmers have become one of Nigeria's most constant security challenges and have left thousands of people displaced and dead in recent years (Vanguard, January 11, 2018). Crisis in these locations have adversely affected food production and supply, because when there is crisis in these locations, there would be further challenge on food security which would in turn result to the challenge of food shortage in supply to the various parts of the country where demands are high, leading to higher prices and scarcity. There could also be wastage of scarce food resources due to emergence of crisis that could prevent distribution.

\subsection{Results from econometric analysis}

This sub-section of the study presents the econometric method. The starting point of presenting the econometric result is by presenting the summary statistics of the variables as shown in Table 2 . The results show the summary statistics of the selected variables that were engaged in this study, the variables are as aforementioned. The mean, standard deviation, minimum and maximum are as presented, to bring to bear the real information required for the study 
Table 2. Summary statistics of variables.

\begin{tabular}{ccccc}
\hline Variable & Mean & $\begin{array}{c}\text { Standard } \\
\text { Deviation }\end{array}$ & Minimum & Maximum \\
\hline Number of people undernourished & 10.81 & 1.48 & 8.80 & 14.30 \\
\hline Agricultural production & 3707.31 & 4405.70 & 38.24 & 14709.10 \\
\hline Agricultural credit guarantee scheme fund & 3827678 & 4325308 & 80845.80 & 1.30 \\
\hline Population & 1.28 & 3.07 & 8.36 & 1.86 \\
\hline Voice and accountability & -0.77 & 0.30 & -1.55 & -0.46 \\
\hline Political stability and absence of violence & -1.92 & 0.20 & -2.19 & -1.52 \\
\hline control of corruption & 17.10 & 10.13 & 0.70 & 28.00 \\
\hline Rule of law & 1.14 & 0.19 & 0.72 & 1.43 \\
\hline
\end{tabular}

Source: Authors' using STATA 13

\subsection{Unit root test for stationarity}

To conduct the ARDL effectively, the unit root test for stationarity was conducted to determine the integrating order of the selected variables. This is considered as a necessary step in order to validate the assumption that none of the variables should be stationary at second differenced (that is, I [2]). This assumption is aimed at preventing the issue of 'spurious result. Insight of the ARDL methodology was drawn from the empirical work of Ouattara et al. (2006). Ouattara et al. (2006) has it that F-statistic that Pesaran (2007) presented seems ineffective when differentiated at order two [I (2)], since the method is based on the premise that variables either co-integrated at order zero [I (0)] or co-integrated at order one [I (1)]. Therefore, engaging a unit root tests in the ARDL approach to cointegration is to ensure that none of the variables is integrated of order 2 as presented in Table 3

Table 3. Unit root test for stationarity

\begin{tabular}{ccccc}
\hline Variables & DF t-statistic & Critical value 5\% & $\begin{array}{c}\text { Integration } \\
\text { order }\end{array}$ & Remark \\
\hline Number of people undernourished & -2.75 & -1.96 & $\mathrm{I}(1)$ & Stationary \\
\hline Agricultural production & 17.10 & -1.95 & $\mathrm{I}(0)$ & Stationary \\
\hline Agricultural credit guaranteed scheme fund & -4.67 & -3.69 & $\mathrm{I}(1)$ & Stationary \\
\hline Population & 4.83 & -1.95 & $\mathrm{I}(1)$ & Stationary \\
\hline Voice and accountability & -2.18 & -1.95 & $\mathrm{I}(0)$ & Stationary \\
\hline Political stability/Absence of Violence & -5.31 & -3.82 & $\mathrm{I}(1)$ & Stationary \\
\hline Control of corruption & -4.41 & -3.67 & $\mathrm{I}(1)$ & Stationary \\
\hline Rule of law & -3.91 & -3.71 & $\mathrm{I}(0)$ & Stationary \\
\hline
\end{tabular}

Note: DF means Dickey Fuller. Source: Authors' using STATA 13.

Table 4. ARDL Short-run relationship.

\begin{tabular}{|c|c|c|c|c|c|c|c|c|c|c|c|c|c|}
\hline \multicolumn{2}{|c|}{$\begin{array}{l}\text { Agriculture } \\
\text { Production }\end{array}$} & \multicolumn{2}{|c|}{ Agricultural credit } & \multicolumn{2}{|c|}{ Population } & \multicolumn{2}{|c|}{$\begin{array}{c}\text { Voice and } \\
\text { accountability }\end{array}$} & \multicolumn{2}{|c|}{$\begin{array}{l}\text { Political } \\
\text { situation }\end{array}$} & \multicolumn{2}{|c|}{$\begin{array}{l}\text { Control of } \\
\text { corruption }\end{array}$} & \multicolumn{2}{|c|}{ Rule of law } \\
\hline L1D & L2D & & & & & & & & L2D & & & & L2D \\
\hline $\begin{array}{c}-0.05 \\
(0.00) \\
{[0.00 *]}\end{array}$ & $\begin{array}{c}-0.030 \\
(0.17) \\
{\left[0.01^{* *}\right]}\end{array}$ & $\begin{array}{c}-1.06 \\
(0.35) \\
{[0.02 * *]}\end{array}$ & & & & & & $\begin{array}{l}-0.21 \\
(0.40)\end{array}$ & & $\begin{array}{c}0.03 \\
(0.02) \\
{[0.11]}\end{array}$ & $\begin{array}{c}0.03 \\
(0.02) \\
{\left[0.00^{*}\right]}\end{array}$ & & \\
\hline
\end{tabular}

Note: Dependent Variable: Number of People undernourished. The standard error and the probability values are in parenthesis () and [] respectively. LD means that the variables are lagged and differenced. *,** means that variables are statically significant at $1 \%$ and $5 \%$ respectively, while LD shows that variables are lagged and differenced. Source: Authors’ using STATA 13. 
Table 5. ARDL Long-run relationship.

\begin{tabular}{ccccccc}
\hline Agricultural production Agriculture credit Population & $\begin{array}{l}\text { Voice \& } \\
\text { accountability }\end{array}$ & $\begin{array}{c}\text { Political } \\
\text { stability }\end{array}$ & $\begin{array}{c}\text { Control of } \\
\text { Corruption }\end{array}$ & Rule of law \\
\hline-0.02 & -0.18 & 0.74 & 0.51 & -0.69 & 0.63 & -0.29 \\
$(0.00)$ & $(0.10)$ & $(0.19)$ & $(0.68)$ & $(0.40)$ & $(0.08)$ & $(0.05)$ \\
{$\left[0.01^{* *}\right]$} & {$\left[0.09^{* *}\right]$} & {$\left[0.08^{* *}\right]$} & {$[0.52]$} & {$\left[0.00^{*}\right]$} & {$[0.468]$} & {$\left[0.05^{* * *}\right]$} \\
\hline
\end{tabular}

Note: Dependent Variable: Number of People undernourished. The standard error and the probability values are in parenthesis () and [] respectively. ${ }^{* * *}, * * *$ means that variables are statically significant at $1 \%, 5 \%$ and $10 \%$ respectively. Source: Authors' using STATA 13 .

The study's econometric method, using the ARDL cointegration approach, focuses on the long-run and short-run relationship as presented in Tables 4, 5. The ARDL results show that there exists a long run relationship food security indicator (number of people undernourished), agriculture indicators (agricultural production and agricultural guarantee scheme fund), indicators of governance and accountability (voice and accountability, political stability and absence of violence, control of corruption and rule of law) and population. The result shows that in the long-run increase in agricultural production reduces the number of undernourished people by $2.89 \%$, agricultural credit guarantee scheme fund to farmers enhance food production base thereby reducing undernourishment by $18.6 \%$. Akin to Malthusian population theory, increase in population increases undernourishment by $74.8 \%$, the reason for this high increase is because of low food production and many people chase little available food produced. Based on governance and accountability, the increase in corruption rate affects undernourishment by $3.94 \%$, political stability and absence of violence contribute to the attainment of food security. It is confirmed in this study that corruption weakens the system and as result increases undernourishment by $0.74 \%$ and $21.06 \%$ respectively. The result from the error correction mechanism is presented in Table 6 is

Table 6. Estimates from error correction mechanism (measurement identifiers see Table 1).

\begin{tabular}{|c|c|c|c|c|c|c|c|c|}
\hline $\begin{array}{c}\text { Regress and } \\
\text { Regressors }\end{array}$ & D_npu & D_agricpro & D_acgsf & D_pop & D_va & D_psav & D_cc & D_rlaw \\
\hline \multirow[t]{2}{*}{ ECterm } & $-0.0245^{*}$ & $-0.3137^{*}$ & $-0.0351 *$ & $-051087 * *$ & $-0.0951^{*}$ & -0.0038 & $-0.5561 *$ & $-0.0481 *$ \\
\hline & $(0.000)$ & $(0.002)$ & $(0.004)$ & $(0.035)$ & $(0.545)$ & $(0.142)$ & $(0.000)$ & $(0.000)$ \\
\hline \multirow[t]{2}{*}{$\mathrm{Npu}(\mathrm{LD})$} & $0.9216^{*}$ & -586.9926 & $-0.3541 *$ & -21282.73 & 0.1709 & 0.115773 & $-9.5024 *$ & $-0.599 *$ \\
\hline & $(0.000)$ & $(0.179)$ & $(0.000)$ & $(0.315)$ & $(0.538)$ & $(0.441)$ & $(0.000)$ & 0.000 \\
\hline \multirow[t]{2}{*}{ agricpro (LD) } & -0.00048 & -0.0345 & $-1117.83^{* *}$ & -9.1983 & $0.0202 * *$ & $0.0017 * * *$ & $-0.0116^{*}$ & $-0.003 * *$ \\
\hline & $(0.034)$ & $(0.856)$ & $(0.0229)$ & $(0.660)$ & $(0.0430)$ & $(0.060)$ & $(0.000)$ & $(0.032)$ \\
\hline \multirow[t]{2}{*}{$\operatorname{acgsf}(\mathrm{LD})$} & $4.0809 *$ & $0.01216^{* * *}$ & & 0.00 & -2.1508 & $-4.0408 * *$ & $-2.4909 *$ & 2.208 \\
\hline & $(0.000)$ & $(0.020)$ & $(0.809)$ & $(0.395)$ & $(0.753)$ & $(0.025)$ & $(0.001)$ & 0.544 \\
\hline \multirow[t]{2}{*}{ population (LD) } & $-2.8007 *$ & $0.0924 *$ & $1.6065 * * *$ & $1.0465 *$ & -1.9407 & 1.4107 & $0.0121 *$ & $4.7607 *$ \\
\hline & $(0.0000)$ & $(0.000)$ & $(0.068)$ & $(0.000)$ & $(0.456)$ & $(0.113)$ & $(0.000)$ & $(0.001)$ \\
\hline $\mathrm{Va}(\mathrm{LD})$ & $\begin{array}{c}-0.06387^{*} \\
(0.000)\end{array}$ & $\begin{array}{c}-36.72332 * \\
(0.000)\end{array}$ & $\begin{array}{c}-293060.8^{* *} \\
(0.0244)\end{array}$ & $\begin{array}{c}-9665.715 \\
(0.867)\end{array}$ & $\begin{array}{c}-0.25739^{*} \\
(0.008)\end{array}$ & $\begin{array}{l}-0.0464 \\
(0.577)\end{array}$ & $\begin{array}{l}4.7568 \\
(0.003)\end{array}$ & $\begin{array}{l}0.6685^{*} \\
(0.000)\end{array}$ \\
\hline psav (LD) & $\begin{array}{c}-0.5867 * * \\
(0.097)\end{array}$ & $\begin{array}{c}231.2085^{*} \\
(0.000)\end{array}$ & $\begin{array}{c}32.8656^{* *} \\
(0.023)\end{array}$ & $\begin{array}{c}25765.93 * * \\
(0.0427)\end{array}$ & $\begin{array}{l}-0.1919 \\
(0.576) \\
\end{array}$ & $\begin{array}{c}-0.6713^{*} \\
(0.004)\end{array}$ & $\begin{array}{c}0.44084 \\
(0.841)\end{array}$ & $\begin{array}{l}0.2047 \\
(0.365)\end{array}$ \\
\hline $\mathrm{Cc}(\mathrm{LD})$ & $\begin{array}{c}-0.0027^{*} \\
(0.000)\end{array}$ & $\begin{array}{c}-45.1274 * \\
(0.002)\end{array}$ & $\begin{array}{c}24783.82 \\
(0.350)\end{array}$ & $\begin{array}{c}1397.085 \\
(0.386)\end{array}$ & $\begin{array}{c}-.0156096 \\
0.459\end{array}$ & $\begin{array}{c}-.0173928 \\
0.128\end{array}$ & $\begin{array}{c}-.028372 \\
0.26\end{array}$ & $\begin{array}{c}.012685 \\
0.258\end{array}$ \\
\hline rlaw (LD) & $\begin{array}{c}-0.7855^{* *} \\
(0.047) \\
\end{array}$ & $\begin{array}{c}709.4312^{* *} \\
(0.031) \\
\end{array}$ & $\begin{array}{c}-1571.819^{*} \\
(0.000)\end{array}$ & $\begin{array}{c}-6163.004 \\
(0.865) \\
\end{array}$ & $\begin{array}{c}-.180111 \\
(0.705) \\
\end{array}$ & $\begin{array}{l}0.0200 \\
(0.938) \\
\end{array}$ & $\begin{array}{c}6.7578^{*} \\
(0.000)\end{array}$ & $\begin{array}{c}1.1067^{*} \\
(0.000)\end{array}$ \\
\hline \multirow[t]{2}{*}{ Adj. R-sq } & 0.8820 & 0.9804 & 0.6062 & 0.7480 & 0.831 & 0.9095 & 0.7973 & 0.695 \\
\hline & \multicolumn{2}{|l|}{ AIC: 57.97317} & \multicolumn{2}{|c|}{ HQIC: 59.21476} & \multicolumn{2}{|c|}{ SBIC: 62.14865} & & \\
\hline
\end{tabular}

Note: $* * *, * *$ means that variables are statically significant at $1 \%, 5 \%$ and $10 \%$ respectively, while LD shows that variables were lagged and differenced based on Akaike information criterion (AIC), Hannan-Quinn information criterion (HQIC) and Schwarz's Bayesian information criterion (SBIC). LD means lagged and differenced Source: The Authors'. 


\section{Conclusion}

Accountability in ensuring food security is a multifaceted assignment, as it is subjective by collective factors operating at diverse tiers of the social-ecological model. These factors comprise the accessibility to a sufficient food supply and access to food from the federal to the state and local government levels. Access to the food supply is in turn mainly influenced by agricultural production; this means that; the higher the production, the more people gain access to food. At Macro-level, food access is driven by factors such as food prices, job opportunities, minimum wages, and social protection policies or programs. The relationship among central, state and local systems of food are characterized by boundaries drifting and high level of insecurity, which makes attempts at steering even more complicated. This is the reason why food security governance, which considers all the drivers, governing activities, and policy outputs and outcomes involved in feeding the population, has gained so much interest as a field of study in recent years

This study explores the importance of food security in Nigeria, considering accountability and governance as key variables. The study found that it is a worthwhile practice for Nigeria to pursue stability as this can form a background to channel the national economy to address food shortage challenges. This could be done through an aggressive support initiative and other pragmatic actions to engage stakeholders to embark on effective food production and distribution that meet household demands. In order to meet households food demand, agricultural incentives should be granted to farmers to increase food production, this is evident from the result obtained in the study which shows that in the long-run increase in agricultural production reduces the number of undernourishment by $2.89 \%$, agricultural credit guarantee scheme fund to farmers enhance food production base thereby reducing undernourishment by $18.6 \%$. Also, the focus on preservation logistics would also be needed to augment current effort to solve identified problems.

\section{Acknowledgment}

The authors appreciate the helpful comments from the anonymous reviewers. The initial version of the paper was presented at the $13^{\text {th }}$ Annual Conference of The Academy of Management Nigeria, Federal University Otuoke, Bayelsa State, Nigeria, September 25 - 26, 2019; hence, comments from the conference participants are appreciated. In addition, the Equipment Subsidy Grant awarded by the Alexander von Humboldt Foundation [REF: 3.4-8151/19047] to Centre for Economic Policy and Development Research (CEPDeR), Covenant University that facilitated the revision of the paper is acknowledged.

\section{References}

Ajayi, C. O., \& Adenegan, K. O. (2018). Rights-based approach to food and nutrition security in Nigeria. In A. E. Obayelu (Ed.), Food systems sustainability and environmental policies in modern economies (pp. 217-234). USA: IGI Global. http://dx.doi.org/10.4018/978-1-5225-3631-4.ch010.

Androsova, I. V., Melnichuk, A. V., Bondaletov, V. V., Vinichenko, M. V., \& Duplij, E. V. (2016). On the issue of state support of agriculture: regional aspect. International Journal of Economics and Financial Issues, 6(1 Suppl), 1-6.

Ayotamuno, J. M., \& Gobo, A. E. (2004). Municipal solid waste management in Port Harcourt, Nigeria: obstacles and prospects. Management of Environmental Quality, 15(4), 389-398. http://dx.doi.org/10.1108/14777830410540135

Babatunde, R. O., Omotesho, O. A., \& Sholotan, O. S. (2007). Socio-economic characteristics and food security status of farming households in Kwara State, North-Central Nigeria. Pakistan Journal of Nutrition, 6(1), 49-58. http://dx.doi.org/10.3923/pjn.2007.49.58

Bélières, JF, Benoit-Cattin, M., Barret, L., Djouara, H., \& Kebe, D. (2008). Producer organizations in the cotton zone in Mali. Conditions of emergence and perspectives. Rural Economy, Agricultures, Foods, Territories, 303-304-305, 22-38. https://doi.org/10.4000/economierurale.498

Candel, J. J. (2014). Food security governance: A systematic literature review. Food Security, 6(4), 585-601. http://dx.doi.org/10.1007/s12571-014-0364-2

Dias, B. G., Juliana, R. P., Giller, K. E., \& Ittersum, M. K. (2017). Agriculture, food security and the sustainable development goals: theory and practice in three development contexts. In Proceedings of the 3rd International Conference on Global Food Security Conference. Cape Town: NRF. 
Echebiri, R. N., \& Edaba, M. E. I. (2008). Production and utilization of cassava in Nigeria: Prospects for food security and infant nutrition. PAT, 4(1), 38-52.

Ejikeme, J. O., Ojiako, J. C., Onwuzuligbo, C. U., \& Ezeh, F. C. (2017). Enhancing food security in Anambra state, Nigeria using remote sensing data. Environmental Review, 6(1), 27-44.

Fogel, R. W. (2004). The escape from hunger and premature death, 1700-2100: Europe, America, and the Third World (Vol. 38). Cambridge: Cambridge University Press. http://dx.doi.org/10.1017/CBO9780511817649.

Food and Agricultural Organization of the United Nations - FAO. (2017). World agriculture: Towards 2015/2030 (pp. 4-8). Geneva: FAO Corporate Document Repository.

Fritschel, H., Carter, T., Stedman-Edwards, P., \& Whitehead, J. (2015). Global nutrition report 2015: Actions and accountability to advance nutrition and sustainable development. Washington: IFPRI.

Herbel, D., Crowley, E., Ourabah, H., \& Lee, M. (2012). Good practices in building innovative rural institutions to increase food security. Rome: FAO.

Ike, C. U., Jacobs, P. T., \& Kelly, C. (2017). A multidimensional approach to measuring household food security in Taraba State, Nigeria: comparing key indicators. Development in Practice, 27(2), 234-246. http://dx.doi.org/10.1080/09614524.2017.1281225 Jhingan, M.L. (2003). The economics of development and planning (36th ed). Delhi: Vrinda Publications.

Lele, U., Masters, W. A., Kinabo, J., Meenakshi, J. V., Ramaswami, B., \& Tagwireyi, J. (2016). Measuring food and nutrition security: An independent technical assessment and user's guide for existing indicators. Rome: Food Security Information Network, Measuring Food and Nutrition Security Technical Working Group.

Matthew, O. A., Osabohien, R., Ogunlusi, T. O., \& Edafe, O. (2019b). Agriculture and social protection for poverty reduction in ECOWAS. Cogent Arts \& Humanities, 6(1), 1682107. http://dx.doi.org/10.1080/23311983.2019.1682107

Matthew, O., Osabohien, R., Urhie, E., Ewetan, O., Adediran, O., Oduntan, E., \& Olopade, C. (2019a). Agriculture as a stimulant for sustainable development in ECOWAS. Sustainability: The Journal of Record, 12(4), 215-225. http://dx.doi.org/10.1089/sus.2018.0039

Munene, M. B., Swartling, A. G., \& Thomalla, F. (2018). Adaptive governance as a catalyst for transforming the relationship between development and disaster risk through the Sendai Framework? International Journal of Disaster Risk Reduction, 28 653-663. http://dx.doi.org/10.1016/j.ijdrr.2018.01.021

Ojo, S. O. (2004). Improving labour productivity and technical efficiency in food crop production: A panacea for poverty reduction in Nigeria. Journal of Food Agriculture and Environment, 2, 227-231.

Osabohien, R., Afolabi, A., \& Godwin, A. (2018a). An econometric analysis of food security and agricultural credit facilities in Nigeria. The Open Agriculture Journal, 12(1), 227-239. http://dx.doi.org/10.2174/18743331501812010227

Osabohien, R., Osabuohien, E., \& Urhie, E. (2018b). Food security, institutional framework and technology: examining the nexus in Nigeria using ARDL approach. Current Nutrition and Food Science, 14(2), 154-163. PMid:29853816. http://dx.doi.org/10.2174/1573401313666170525133853

Osabuohien, E., Okorie, U., \& Osabohien, R. (2018c). Rice production and processing in Ogun State, Nigeria: qualitative insights from Farmers' Association. In E. Obayelu (Eds.), Food systems sustainability and environmental policies in modern economics (pp. 188-215), Hershey, PA: IGI Global. http://dx.doi.org/10.4018/978-1-5225-3631-4.ch009.

Osabohien, R., Akinpelumi, D., Matthew, O., Okafor, V., Iku, E., Olawande, T., \& Okorie, U. (2019a). Agricultural exports and economic growth in Nigeria: An econometric analysis. IOP Conference Series: Earth and Environmental Science, 331(1), 012002. https://doi.org/10.1088/1755-1315/331/1/012002

Osabohien, R., Matthew, O., Gershon, O., Ogunbiyi, T., \& Nwosu, E. (2019b). Agriculture development, employment generation and poverty reduction in West Africa. The Open Agriculture Journal, 13(1), 82-89. http://dx.doi.org/10.2174/1874331501913010082

Osabohien, R., Matthew, A. O., Aderounmu, B., \& Olawande, T. (2019c). Greenhouse gas emissions and crop production in West Africa: Examining the mitigating potential of social Protection. International Journal of Energy Economics and Policy, 9(1), 57-66.

Osabohien, R., Osuagwu, E., Osabuohien, E., Ekhator-Mobayode, U.E., Matthew, O., \& Gershon, O. (2020). Household access to agricultural credit and agricultural production in Nigeria: A propensity score matching model. South African Journal of Economic and Management Sciences, 22(1), a2688. https://doi.org/10.4102/sajems.v23i1.2688

Ouattara, K., Ouattara, B., Assa, A., \& Sédogo, P. M. (2006). Long-term effect of ploughing, and organic matter input on soil moisture characteristics of a Ferric Lixisol in Burkina Faso. Soil \& Tillage Research, 88(1-2), 217-224. http://dx.doi.org/10.1016/j.still.2005.06.003

Pesaran, M. H. (2007). A simple panel unit root test in the presence of cross-section dependence. Journal of Applied Econometrics, 22(2), 265-312. http://dx.doi.org/10.1002/jae.951

Rodrik, D. (2010). Diagnostics before prescription. The Journal of Economic Perspectives, 24(3), 33-44. http://dx.doi.org/10.1257/jep.24.3.33

Scribner, S. (2017). On the brink: As famine looms, world leaders must pay up and deliver political solutions to save lives. OXFAM Briefing Nota. Retrieved in 2017, May 19, from oxfamilibrary.openrepository.com/handle/10546/620268

Shamah-Levy, T., Mundo-Rosas, V., Flores-De la Vega, M. M., \& Luiselli-Fernández, C. (2017). Food security governance in Mexico: how can it be improved? Global Food Security, 14, 73-78. http://dx.doi.org/10.1016/j.gfs.2017.05.004 
Sidibé, A., Totin, E., Thompson-Hall, M., Traoré, O. T., Traoré, P. C. S., \& Olabisi, L. S. (2018). Multi-scale governance in agriculture systems: interplay between national and local institutions around the production dimension of food security in Mali. NJAS Wageningen Journal of Life Sciences, 84, 94-102. http://dx.doi.org/10.1016/j.njas.2017.09.001

Thi, N. B. D., Kumar, G., \& Lin, C. Y. (2015). An overview of food waste management in developing countries: current status and future perspective. Journal of Environmental Management, 157, 220-229. PMid:25910976. http://dx.doi.org/10.1016/j.jenvman.2015.04.022

Titus, B., \& Adetokunbo, G. (2007). An analysis of food security situation among Nigerian urban households: Evidence from Lagos State, Nigeria. Journal of Central European Agriculture, 8(3), 397-406.

Ufua, D. E., Papadopoulos, T., \& Midgley, G. (2015). Enhancing lean interventions through the use of systems thinking in the food production industry: a case in the Niger Delta region of Nigeria. Journal of the International Society for the Systems Sciences, 1(1), 1-24.

Ufua, D. E., Papadopoulos, T., \& Midgley, G. (2018). Systemic lean intervention: enhancing lean with community operational research. European Journal of Operational Research, 268(3), 1134-1148. http://dx.doi.org/10.1016/j.ejor.2017.08.004

Womack, J. P., \& Jones, D. T. (2003). Lean thinking: Banish waste and create wealth in your corporation (2nd ed.). London: Simon and Schuster.

World Bank. (2019a). World development indicators. Washington: World Bank.

World Bank. (2019b). World governance indicators. Washington: World Bank. 